\title{
THE CHALLENGES FACED BY AFRICAN FEMALES IN THE CONSTRUCTION INDUSTRY. EVIDENCE FROM A SELECTED METROPOLIS OF THE EASTERN CAPE
}

\begin{abstract}
The South African construction industry has successfully held a positive role in the transformation of the country over the years through economic development, infrastructure, and job creation. The purpose of the study was to probe the challenges that hinder the progress of black female professionals to become successful entrepreneurs in the construction industry. The study pursued a quantitative research approach. A questionnaire-based survey was utilized to gather data from participants at the selected location of the Buffalo City Metropole, Eastern Cape. The research findings revealed that although there are still challenges faced by African females, there is still considerable growth of women-owned SMME's and the retention of African female professionals within the construction industry has significantly improved. It was also concluded that the many Government initiatives have also played a key role in these successes, though participants have also noted that there are some areas for improvement on these programs.
\end{abstract}

Keywords: Construction Industry, Economic Development, Transformation, SMME’s.

\section{INTRODUCTION}

The South African construction industry was prior to 1994 dominated by white maleowned entities, this slightly changed during the introduction of Black Empowerment legislation even though, majority of the beneficiaries of this legislation were African Male entrepreneurs. It was only after the year 2010 that female-owned entities started gradually to enter the industry through the employment of academically qualified women (Makonye, 2019). Although the numbers of females enrolling in construction studies and allied courses have increased significantly in the past decade or there however still not enough ownership and representation of African women in managerial or directorial positions in medium to large scale construction companies due to factors that include but are not limited to i)

\footnotetext{
1 Tshepo Tlapana, PhD, Department of Corporate Communications and Marketing, Faculty of Business Science, Walter Sisulu University, Eastern Cape, South Africa; e-mail: ttlapana@wsu.ac.za (corresponding author). ORCID: 0000-0002-1777-6177.

2 Zintle Mngeni, Research Assistant, Advanced Diploma: Marketing, Department of Corporate Communications and Marketing, Faculty of Business Science, Walter Sisulu University, Eastern Cape, South Africa; e-mail: zintlemngeni@gmail.com. ORCID: 0000-0001-6655-061X
} 
industry being male-dominated; ii) obsolete industry trends or standards, and iii) the limited skills transformation to the few women who are already within the Construction industry.

The construction industry plays an integral role in the economic and social growth of a country like South Africa which is still well in its developing and transformational phase. Women in construction continue to face vast and complex challenges in the Construction Industry. The construction industry requires a face-lift to help improve the business or professional participation of more females as this could eventually lead to more and more female role-players through the advancement of the female workforce in construction. Several female professionals already in the construction industry are channeled more into the office or administrative positions such as Construction Projects Coordinators whose main responsibilities would include but are not limited to, developing construction contracts, and preparing progress reports for clients. Whereas on the other hand much of their male counterparts take up more of the strategic professional, technical, and managerial positions in the industry like Architects, Surveyors, and Site Engineers. This significantly impacts the skills transformation across the two gender groups.

The primary goal of this research was to assess and comprehend the challenges that African Females confront while attempting to establish themselves as specialists in the Construction Industry, as well as to investigate the challenges that African Females face when entering the construction industry. The study has been conducted since little is known about the challenges that African females face while attempting to move into the construction sector.

\section{REVIEW OF LITERATURE}

\subsection{Understanding the Construction Industry}

According to Karadağ (2016) the global construction industry accounts for more than $10 \%$ of the global Gross Domestic Product (GDP) and employs approximately $7 \%$ of the global workforce with an estimated output of \$10.8 Trillion globally in 2017. The South African Construction Industry equally plays a crucial role in the nation's economic growth and assist in curbing unemployment. To ensure sustainability and growth for the industry all business sectors of the construction industry mainly Building, Infrastructure, and Industry Facilities need to engage and show commitment to transformation.

Statistics released on the CIDB's Construction Monitor-Transformation (Jan, 2020), it is evident that although there is a positive trajectory on transformation in small to medium enterprises (in terms of CIDB Grading) there is however still very slow progress when it comes to transformation in the bigger higher graded enterprises (Grade 7-9). From this, the major role-playing contractors in the construction industry are still predominantly white male-dominated and owned. Dennis Pillay, chairperson of Co-operative South African Building Contractors and Civils Association as quoted by Ramphele (2018) further claims that Seventy percent of the total work available in construction gets shared amongst the top five construction companies.

Chun, Hung, and Byun (2015) describe the construction industry as the economic sector mainly responsible for infrastructure design, planning, construction, and maintenance, Skeepers and Mbohwa (2015) further elaborate that the South African construction industry plays a crucial role in the country's plans for development through infrastructure. The two arguments further illustrate the importance of this industry in a country's economic and social development, though, Temidayo, Osunsanmi, Aigbavboa and Oke (2018) believe the 
industry is still threatened by activities within and outdated approaches that hinder the integration of women and implementation of Information and Communication Technologies (ICT) in the construction industry.

\subsection{Women-Owned Small, Medium and Micro Enterprises (SMME's) in the Construction Industry}

Makonye (2019) describes the South African construction industry as one characterized by a large number of small firms that subcontract from larger firms. In a case study by Adendorff, Appels, and Botha (2011) it is further discussed how the growth and development of a strong robust SMME base can lead to the long-term betterment of the country's economy. The Construction Industry Development Board (CIDB) released an online report (A Study of Grade 1 Contractors 2020) in which it is outlined that women are generally under-represented in construction entrepreneurship and further states that most of those women-owned contractors who are formally registered with the CIDB are marked as inactive due to issues which include but not limited to lower educational experiences and obstacles to accessing finance. Haupt and Fester (2012) also observed that the estimated ratio of men to women employees in the construction industry is greater than 2:1. Furthermore, women generally struggle to climb up the hierarchy in the workplace or even when they decide to venture into their businesses within the construction industry due to this lack of strategic skill-sets.

The majority of women-owned SMME's resort to sub-contracting as a growth strategy due to the above-mentioned factors and as per the CIDB's online publication (2020). Subcontracting in the South African construction industry carries a lesser financial risk for the growing SMME and presents development opportunities. Zizile and Tendai (2018) further summarized that amongst other things entrepreneur competencies have a great impact on the survival of SMME's in East London, their study concluded that the performance of women-owned SMME's in East London is significantly dependent on the relationship between risk-taking, envisioning opportunities and innovative skills set.

The South African Women in Construction(SAWiC) was formed in 1997 with the initial focus on training, advocacy, and support to women mainly in housing construction (Ndinda, 2009). SAWiC directly works with Government departments such as Public Works, Human Settlements to actively promote and support women in the construction industry to successfully establish and sustain profitable business enterprises nationally. Ssekibuule (2012) further explains that SAWiC also assists women contractors to gain access not only to housing finance but also supports women contractors secure contracts and networks in the broader construction industry.

\subsection{Government Intervention}

The South African government has continuously put measures that are aimed at the progression of local economic development while also pushing for contractor involvement in adherence and support for policies and regulations relating to Black Economic Empowerment (BEE), training and skills development (CIDB, 2020).

CIDB (2020) outlines key factors concluded from the Construction Industry Transformation Summit a framework to advance transformation within the construction industry, from that framework highlights the importance of the participation of not only black contractors but also black-women-owned contractors both in the public and private sectors. According to their annual report of 2018 to 2019, the BCMM implemented through 
the Expanded Public Works Programme (EPWP) mechanisms within the city to support community development such as the Vukuphile Contractor Programme (BCM Annual Report, 2018/19 FY). The government also works hand in hand with reputable councils in the province such as the South African Women in Construction (SAWIC) to help bridge the gaps identified.

The Expanded Public Works Programme (EPWP) is a flagship initiative of the Department of Public Works launched in April 2004, implemented in all nine provinces which were aimed at alleviating poverty and unemployment through skills development and job creation in the previously disadvantaged communities (Mkhatshwa-Ngwenya, 2016). Dladla and Mutambara (2018) in their study revealed that the majority of participants in the Government's Expanded Public Works Programme were mainly women, and through their study survey found that over $95 \%$ of the participants were convinced of the effectiveness of the program in assisting them with their businesses and enhancing their managerial skills. One of the key observations as highlighted by Mkhatshwa-Ngwenya (2016) is the fact that the EPWP was never initially designed or planned as a long-term employment opportunity for the unskilled but rather as an emergency poverty alleviation and skills development program. The Buffalo City Metropolitan Municipality encountered some challenges implementing the EPWP phases and targets, and as discussed by Jikwana (2017) these included but were not limited to lack of political and administrative support and poor improper planning.

The Vukuphile Contractor Programme(VCP) is another programme created to accelerate the skills development of emerging contractors with regards to administrative, technical, managerial, and entrepreneurial aspects of business for these emerging contractors to be equally competent in bidding and execution of big labour-intensive projects.

The VCP incorporated a learnership program the Vukuphile Learnership Programme (VLP) which assisted qualifying emerging contractors with the required theoretical and practical skills over three years leading to a National Qualification Framework (NQF) recognized qualification (Maholwana, 2015). This would then boost the emerging contractor's chances of upgrading from a Grade 1 and Grade 2 on the CIDB's to a higher grading.

\section{METHODOLOGY}

An exploratory research approach using the quantitative research method was adopted for this study. The quantitative research method was selected based on the purpose of the study, the quantitative research method allowed for the incorporation of a wide range of methods concerned with the systematic investigation of socio-economic challenges with the use of statistics and numerical data. According to Hughes, Cresswell, and Cresswell (1996), quantitative research further allows for ease of analyses and interpretation of results, Ghauri, Grønhaug, and Strange (2020), further ascertains this notion by adding that quantitative research can be represented in a form of charts and graphs.

The research used a sample size of 20 participants, spread over five different companies actively involved in the Construction Industry of the Eastern Cape particularly was deemed as a necessary minimum to effectively provide enough information to produce concrete findings. Due to the country's current state of disaster, 20 participants were deemed 
sufficient and were within means of reach without having to exhaust travel arrangements which would, in turn, incur unnecessary costs.

Table 1. Number of participants broken down into five companies

\begin{tabular}{|l|l|}
\hline Name of Company & Sample Size \\
\hline Imvelo Quantity Surveyors cc & 4 Respondents \\
\hline Platinum Trading (PTY) LTD & 4 Respondents \\
\hline SA Homes Group & 4 Respondents \\
\hline The South African National Road Agency Ltd ( SANRAL) & 4 Respondents \\
\hline Tshiki Consulting Engineers & 4 Respondents \\
\hline Total Number & 20 Respondents \\
\hline
\end{tabular}

Source: own study.

The primary instrument used in the study was self-administered questionnaires, which were distributed amongst 20 willing participants. The questionnaire consisted of 14 questions inclusive of open-ended and close-ended questions.

Data was collected through Self-administered questionnaires which were sent out to all participants who had agreed to take part, these were sent out and received back by scan mail. All returned questionnaires were carefully checked for any errors or incompleteness, the answers were then recorded to be presented in statistics format through bar graphs and pie charts.

\section{RESULTS}

The survey approach was used to acquire primary data. To gather the essential information, a questionnaire was created and pre-tested. Self-administered questionnaires were used to obtain the data. A closed-ended questionnaire with several different options for respondents was used to collect primary data. Descriptive statistics were employed in a study to describe the basic characteristics of the data. They provide concise summaries of the sample and measures. They are the foundation of almost every quantitative data analysis, along with simple graphical analysis.

Figure 1 depicts the racial demographics of the respondents, over $55 \%$ categorized themselves as African, another $30 \%$ were White with a further $15 \%$ of the respondents marked as Indian. This implies that there is a fair share number of African professionals in the construction sector of the Eastern Cape. Sangweni (2015) emphasizes the importance of capturing the race of respondents due to the different cultural backgrounds which may also influence participants' responses.

Figure 2 illustrates that of the 20 participants, 65\% have extensive experience of between 5-10 years with a further $10 \%$ having more than 10 years of experience, the rest are respondents with less than 5 years of experience sitting at $25 \%$. This implies that the construction industry has improved significantly through the yes in terms of retaining their staff, with professionals going well over the 5-year mark of experience. 


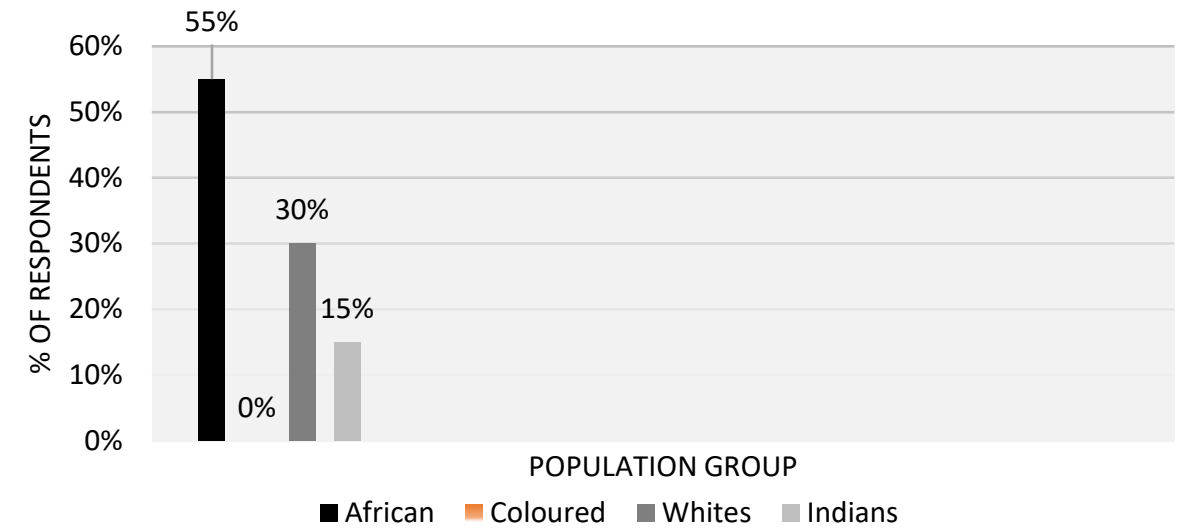

Figure 1. Ethnicity of Respondents

Source: own study.

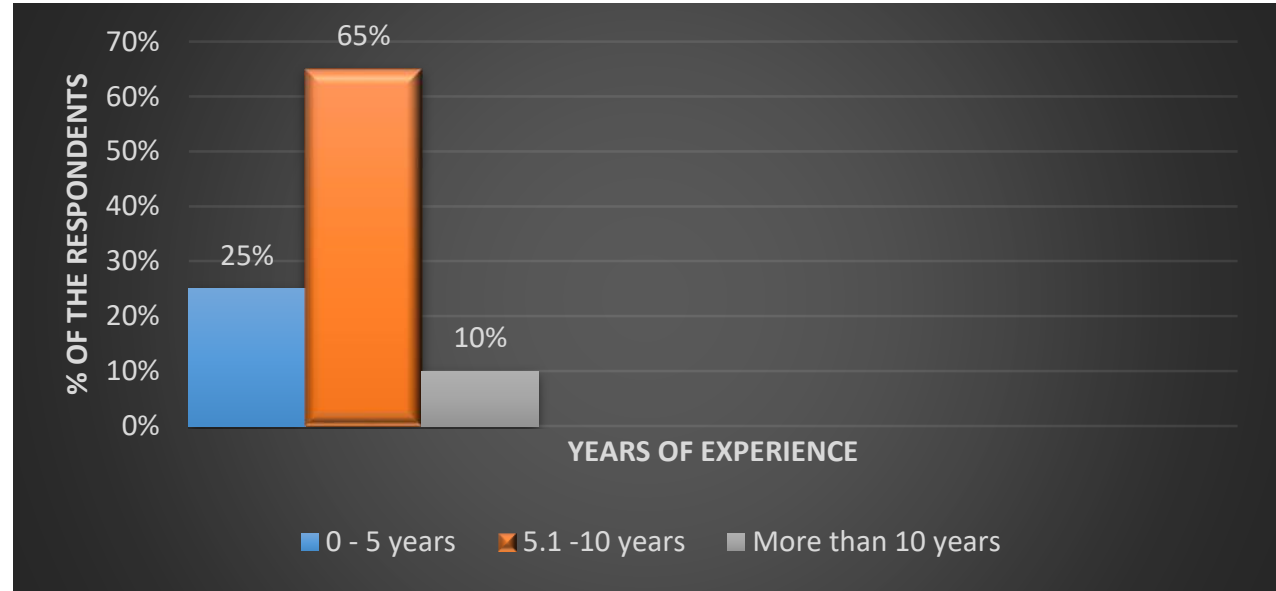

Figure 2. Respondent's work experience in the construction Industry Source: own study. 


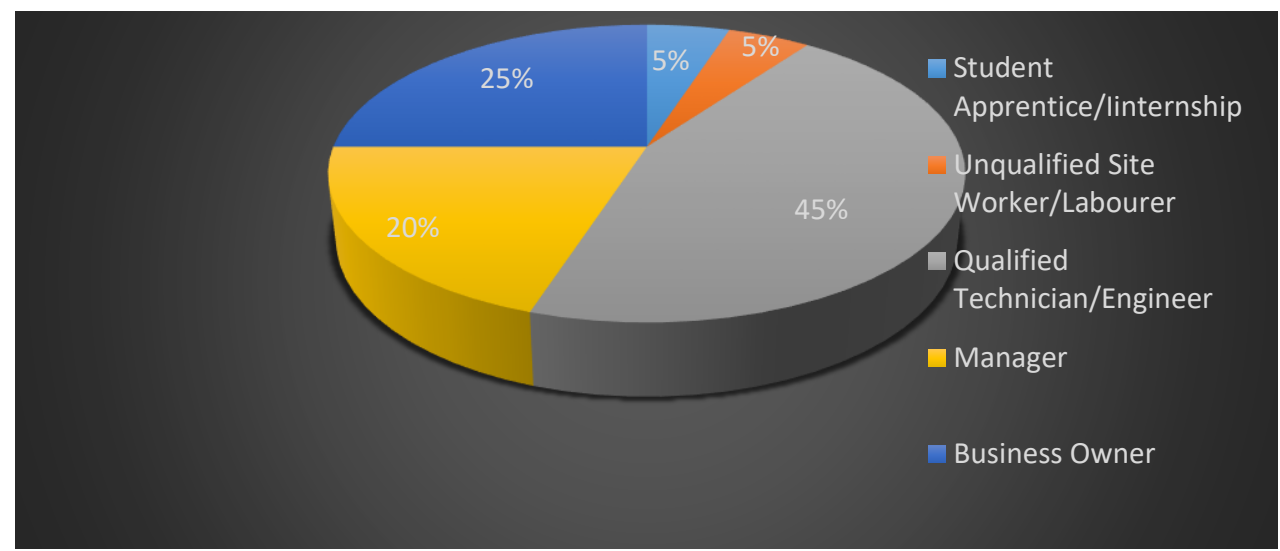

Figure 3. Respondent's position in the construction industry

Source: own study.

Many of the participants are qualified Engineers/Technicians at $45 \%$, followed by the $25 \%$ who are business owners, $20 \%$ are in managerial positions while there is a further $5 \%$ each on those on Internships and those who are unskilled labourers. The above shows that construction is no longer considered an end career with no opportunities for promotions, the above shows.

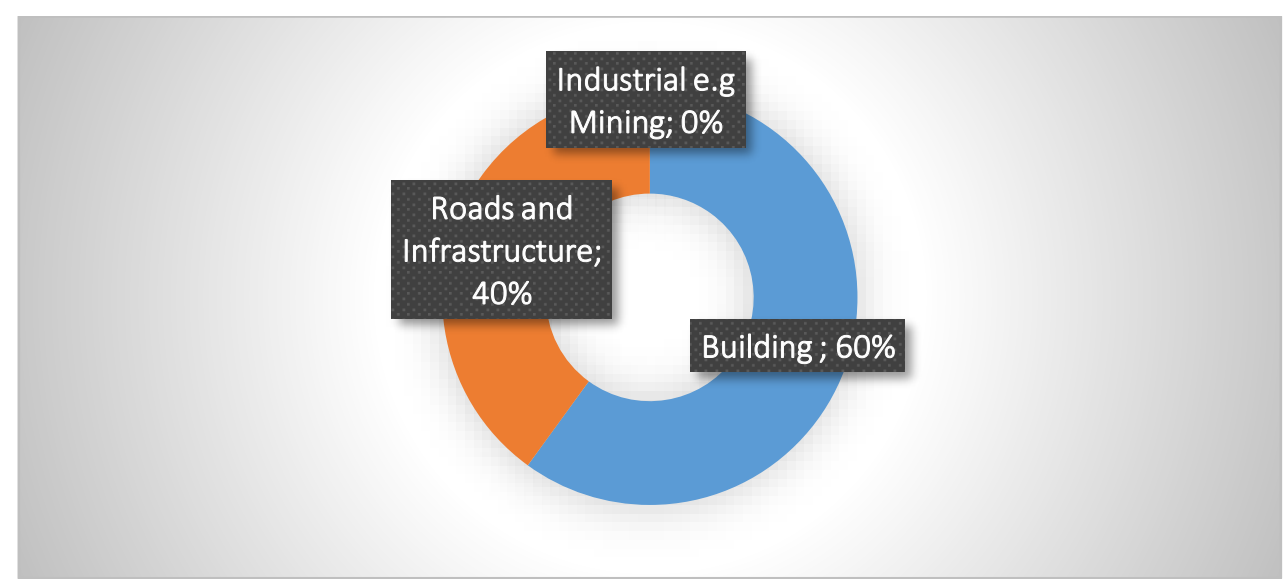

Figure 4. Respondent's area of expertise

Source: own study.

Due to the fewer mining activity in the province of the Eastern Cape, the majority (60\%) of the participants are in the building sector followed by $40 \%$ in the roads and infrastructure sector. This also reveals future opportunities for industry growth in the Eastern Cape beyond only Building and Infrastructure sectors. 
Table 2. Challenges faced by women in the construction industry

\begin{tabular}{|l|c|c|}
\hline \multicolumn{1}{|c|}{ Challenges experienced } & Number of responses (n) & Percentage (\%) \\
\hline $\begin{array}{l}\text { High dominance and stronghold of } \\
\text { male counterparts }\end{array}$ & 14 & $70 \%$ \\
\hline $\begin{array}{l}\text { Women possessing inappropriate } \\
\text { and inadequate skills set for the } \\
\text { construction industry }\end{array}$ & 12 & $60 \%$ \\
\hline $\begin{array}{l}\text { Unequal educational opportunities } \\
\text { presented to women }\end{array}$ & 13 & $65 \%$ \\
\hline High industry standards & 09 & $45 \%$ \\
\hline $\begin{array}{l}\text { Challenges of securing start-up } \\
\text { capital }\end{array}$ & 18 & $90 \%$ \\
\hline Challenge of high industry costs & 16 & $80 \%$ \\
\hline
\end{tabular}

Source: own study.

Results further reveal that women generally encounter a plethora of challenges when trying to venture into the construction industry. Some of these challenges are the inability to secure start-up capital, the high cost of the industry, and unequal educational opportunities. Aneke, Derera, and Bomani (2017) in their study suggest that other challenges facing women entrepreneurs in construction are socio-cultural issues. The authors further explain that the women entrepreneurs to curb these issues often find solutions through forming and belonging to network organizations that provide business support and training and at times forming partnerships with Non-Government Organisations (NGO's) or with the more established women in business.

Participants were asked specifically about the initiatives the local municipality has implemented to uplift female contractors in the industry, very few showed awareness of these programs, proving that the municipality still has work to do to ensure not only awareness but active participation from the developing SMME's in the municipality.

\section{RECOMMENDATIONS}

There should be integration and development of young female professionals to strategic and managerial roles within the construction industry. Corporate organizations need to play a huge role in ensuring that the female professionals are well-groomed and supported to pursue managerial roles within the industry.

The continuation of these government initiatives is very crucial to have an efficacy that is well documented, however proper planning and support from all stakeholders is also equally important to ensure the success of these initiatives. Like the EPWP to be properly planned and budgeted for these to reach the targeted groups and provide a more sustainable long-term solution to the unemployment challenges it was set to curb.

There should be female emerging contractor development programs. Emerging contractors need to identify the type of support that they required through these development programs, enlisting assistance in securing access to finance as key, followed by assistance in securing work and contracts that are to be enhanced in both public and private sectors. 


\section{LIMITATIONS}

Major limitations experienced were mainly due to the current pandemic, with the Government imposing restrictions on travel and gatherings, this meant there was limited opportunity to conduct more one on one interviews or to visit some of the participants at their places of work as some of the participants were on a work from home schedule.

\section{CONCLUSION}

The objectives of the study were to highlight the major challenges faced by women both as professionals and business owners in the construction industry, the study further outlined the survival techniques women in construction have had to develop to have longer sustainable careers in the industry. The study further investigated the role that SMME's and emerging contractors play in the industry, and further highlights the importance to ensure the continuous development of these SMME's through avenues like the CIDB's contractor grading platform.

The study concludes and recommends the need for further research to be conducted into the development of female African contractors in the construction industry of the Eastern Cape. A study of the roles that both local and national government has to play needs to be conducted and reviewed.

\section{REFERENCES}

Adendorff, C., Appels, G., Botha, B. (2011). Strategic management: An Eastern Cape construction SME case study. "Acta Structilia”, 18(2).

Aneke, E. O., Derera, E., Bomani, M. (2017). An exploratory study of challenges faced by women entrepreneurs in the construction industry in South Africa. "International Journal of Business and Management Studies", 9(2).

Buffalo City Metropolitan Municipality, Annual report for 2018/19 Financial Year.

Chun, S. H., Hwang, H. J., Byun, Y. H. (2015). Green supply chain management in the construction industry: Case of Korean construction companies. "Procedia-Social and Behavioral Sciences", 186.

Construction Industry Development Board (CIDB), 2016. Construction Monitor Transformation Q4 2019, viewed 03 October 2020.

Dladla, L., Mutambara, E. (2018). The Impact of Training and Support Interventions on Small Businesses in the Expanded Public Works Programme-Pretoria Region. "Social Sciences", $7(12), 248$.

Demissie, Z. (2020). Effect of Internal Integration on Supply Chain Performance: The Case of Ethiopian Pharmaceutical Supply Agency (Masters Dissertation, Addis Ababa University).

Diko, S. (2015). Barriers to the growth of black-owned construction companies in Buffalo City Metropolitan Municipality: An exploratory study (Doctoral Thesis, University of South Africa).

Ghauri, P., Grønhaug, K., Strange, R. (2020). Research methods in business studies. Cambridge University Press.

Haupt, T., Fester, F. (2012). Women-owned construction enterprises: a South African assessment. "Journal of engineering, design and technology", 10(1). 
Hughes, G. E., Cresswell, M. J., Cresswell, M. M. (1996). A new introduction to modal logic. Psychology Press.

Jikwana, M. V. (2018). Why municipalities do not comply and implement expanded public works programmes: a case study of the Buffalo City Metropolitan Municipality in South Africa (Masters Dissertation, Nelson Mandela University).

Karadağ, H. (2016). The role of SMEs and entrepreneurship on economic growth in emerging economies within the post-crisis era: An analysis from Turkey. "Journal of Small Business and Entrepreneurship Development", 4(1).

Construction Industry Development Board (CIDB), Study of Grade 1 Contractors, Accessed, 02 October 2020.

Maholwana, U. (2015). Support for small enterprises in the construction sector: Coega Development Corporation contractor development programme. Unpublished master's thesis. Stellenbosch University [access: 8.10.2020]. Access on the internet: http://scholar. sun. ac. za/handle/10019.1/97336

Makonye, C. (2019). The effects of individual and organizational factors on ethical behavior in the South African construction industry (Doctoral Thesis).

Mkhatshwa-Ngwenya, E. N. M. (2016). Implementation of the Expanded Public Works Programme (EPWP) in South Africa (2004-2014) (Doctoral Thesis, University of South Africa).

Ndinda, C. (2009). 'But now I dream about my house': women's empowerment and housing delivery in urban KwaZulu-Natal, South Africa. "Development Southern Africa”, 26(2).

Ntwasa, A. (2017). An evaluation of the expanded public works programme in the Buffalo City Metropolitan Municipality, Eastern Cape Province (Masters Dissertation, University of Fort Hare).

Osunsanmi, T. O., Aigbavboa, C., Oke, A. (2018). Construction 4.0: the future of the construction industry in South Africa. "International Journal of Civil and Environmental Engineering", 12(3).

Ozumba, A., Ozumba, C. (2012). Women in construction in South Africa: Investigating the feminine footprint of the South African construction industry. "Journal for the Advancement of Performance Information and Value", 4(1).

Ramphele, L. (May 2018). Construction Industry hasn't changed since the '70's, lacks transformation. Retrieved from Cape Talk.

Sangweni, N. (2015). Women in Construction: Hindrances that shorten the professional working life of female site engineers on construction sites in South Africa (Doctoral Thesis, University of the Witwatersrand).

Skeepers, N. C., Mbohwa, C. (2015). A study on the leadership behaviour, safety leadership and safety performance in the construction industry in South Africa. "Procedia Manufacturing", 4.

Ssekibuule, H. J. F. (2012). An Evaluation of Women Participation In Housing Delivery In The Eastern Cape Province Of South Africa The Case Of The Mdantsane Township In Buffalo City Municipality:1962-2012 (Doctoral Thesis, University of Fort Hare).

Tendai, C. (2012). The impact of entrepreneurship education on the performance of Small, Micro and Medium Enterprises in the Buffalo city metropolitan municipality (Doctoral Thesis, University of Fort Hare). 
Zizile, T., Tendai, C. (2018). The importance of entrepreneurial competencies on the performance of women entrepreneurs in South Africa. "Journal of Applied Business Research (JABR)", 34(2).

DOI: 10.7862/rz.2021.mmr.28

The text was submitted to the editorial office: August 2021.

The text was accepted for publication: December 2021. 
